\title{
NUTRIENT EXPERIMENT USING PHAEODACTYLUM TRICORNUTUM AS AN ASSAY ORGANISM
}

\author{
C. TEIXEIRA \& A. A. H. VIEIRA* \\ Instituto Oceanográfico da Universidade de São Paulo
}

\section{SYNOPS IS}

The growth of Phaeodactylum tricornutum, cultured at 7,000 lux and $25^{\circ} \mathrm{C}$, in twelve-day experiments using enriched water collected at the surface and $50.0 \mathrm{~m}$ depth from coastal waters offshore of Ubatuba area, was carried out. Different water enrichements were made by the aseptic addition of several nutrients, at each depth, according to Smayda (1964). The nitrogen out measured in terms of Carbon-14 assimilation and chlorophyl1 concentration, was found to be a primary limiting factor for marine phytoplankton production.

\section{INTRODUCTION}

The influence of nutrients on phytoplankton growth has been generally assessed only by indirect measurements. Besides, most information on this kind of studies, in spite of their importance, has not been much conclusive.

\footnotetext{
* Fellowship from Fundação de Amparo à Pesquisa do Estado de São Paulo. PUBL. NO 366 DO INST. OCEAN. DA USP.
} 
Bolm Inst. oceanogr., S Paulo, 25, 1976

Ryther \& Guillard 1960, Menzel \& Ryther, 1961 and other authors have employed a more direct method to measure the response of natural populations of phytoplankton, using water samples enriched with several nutrients.

More recently, Smayda, 1964, used bacteria-free cultures "to assay the potential importance of various nutrients when added singly or in combination to filtered sea water by measuring the response of a representative assay organism".

Based on this technique, the authors initiated some investigations on the marine diatom Phaeodactylum tricornutum as to an assay of the potential importance of different nutrients in coastal tropical waters. This paper intends to describe some preliminary results on nutrients enrichment using that marine diatom isolated by the authors from the area studied.

\section{MATERIAL AND METHODS}

The stock cultures of semi-aseptically Phaeodactylum tricornutum were maintained at $25^{\circ} \mathrm{C} \pm 1.0^{\circ} \mathrm{C}$ in $250 \mathrm{ml}$ "Pyrex" flasks under constant illumination of 7,000 lux from "white" fluorescent tubes. The Guillard's medium " $f$ " used for cultures was prepared in accordance with Guillard (1963). The position, environmental and hydrographic conditions of the station are reported in Table I. Water samples were collected at the surface and at $50.0 \mathrm{~m}$ depth. The samples were filtered through a "Millipore-HA" filter to remove the natural plankton and particulate matter. Aliquots of $100 \mathrm{ml}$ filtered sea-water were transferred to transparent $250 \mathrm{ml}$ presterilized erlenmeyer vessels plugged with cotton wool. At each depth, different enrichments were made by the following aseptic addition of nutrients in accordance with Smayda (1964): 
TRACE METALS

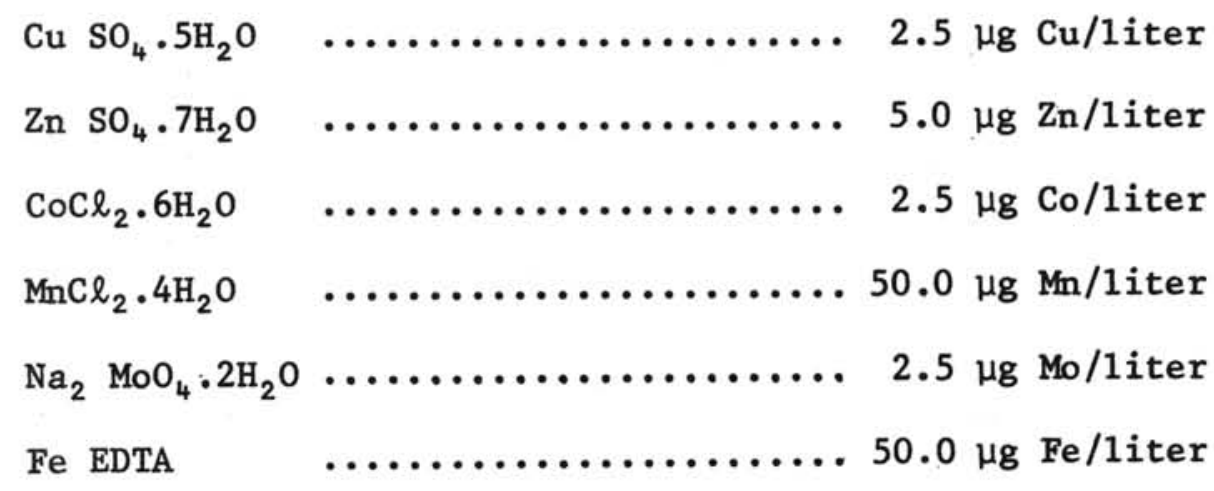

VITAMINS

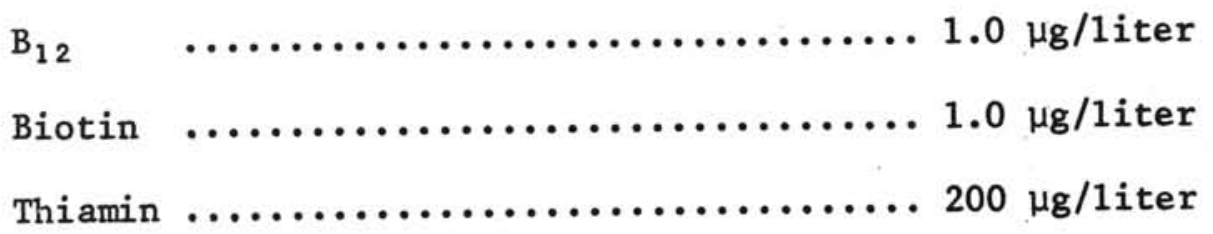

Based on these inorganic and vitamins nutrients, eleven different combinations of the medium were used:
a) $\mathrm{Na} \mathrm{H} \mathrm{H}_{2} \mathrm{PO}_{4} \cdot \mathrm{H}_{2} \mathrm{O}$
b) $\mathrm{NaNO}_{3}$
c) $\mathrm{Na} \mathrm{H} \mathrm{H}_{2} \mathrm{PO}_{4} \cdot \mathrm{H}_{2} \mathrm{O}+\mathrm{NaNO}_{3}$
d) $\mathrm{Na} \mathrm{H} \mathrm{H}_{2} \mathrm{PO}_{4} \cdot \mathrm{H}_{2} \mathrm{O}+\mathrm{NaNO}_{3}+\mathrm{Na}_{2} \mathrm{SiO}_{3} \cdot 9 \mathrm{H}_{2} \mathrm{O}$
e) $\mathrm{Na} \mathrm{H}_{2} \mathrm{PO}_{4} \cdot \mathrm{H}_{2} \mathrm{O}+\mathrm{NaNO}_{3}+\mathrm{Fe}$ EDTA $(50.0 \mu \mathrm{g} \mathrm{Fe} /$ liter $)$
f) Fe EDTA
g) $\mathrm{Na} \mathrm{H}_{2} \mathrm{PO}_{4} \cdot \mathrm{H}_{2} \mathrm{O}+\mathrm{NaNO}_{3}+$ vitamins $\left(\mathrm{B}_{12}\right.$, Biotin, Thiamin)
h) vitamins ( $B_{12}$, Biotin, Thiamin)
i) trace metals
j) complete medium
1) no nutrient added (none) 
Culture flasks were inoculated with semi-axenic Phaeodactylum tricornutum. The inocula varied from 15 to $25 \times 10^{3} \mathrm{cels} / \mathrm{ml}$, but they were the same for each depth studied. Flasks were incubated at 7,000 lux using fluorescent tubes, at a temperature of $25^{\circ} \mathrm{C}$ during ten days in a BOD cabinet. Chlorophy11-a concentration was assessed after the method described by Richards \& Thompson (1952) and computed by Parsons \& Strickland equations (1963). For photosynthesis measurements samples were placed in BOD cabinet, injected with $4.0 \mu \mathrm{Ci} \mathrm{C}^{14}$, as $\mathrm{NaHCO}_{3}$, and incubated under artificial light at 7,000 lux for four hours. Bottles wrapped in aluminium foil were similarly used to evaluated $\mathrm{C}^{14}$ dark fixation and to verify possible bacterial contamination. After the incubation period, samples were filtered on Millipore filters ( $\mathrm{HA})$ and dried in a desicator. $\beta$-countings were performed on a Philips low-level $\beta$-counter. The efficiency of the system is $8 \%$.

\section{RESULTS}

The investigations carried out to assay the potential importance of various nutrients in the coastal Brazilian waters concerning to $50.0 \mathrm{~m}$ depth (Table I), showed the following results: the addition of phosphate diminishes from 48.0 to $72.0 \%$ against the control in terms of $\mathrm{c}^{14}$ assimilation and from 16.0 to $24.0 \%$ in terms of chlorophyll concentration. Nitrate enrichments produced increases from 8.0 to $52.0 \%$ relatively to the control in terms of carbon assimilation and from 60.0 to $92.0 \%$ against the control to chlorophy11 synthesis. On the other hand the nitrate-phosphate enrichment together was rather conspicuous, leading to an increase from 168.0 to $344.0 \%$ in terms of carbon assimilation and from 88.0 to $112.0 \% \mathrm{rela}-$ tively to chlorophyll concentration. However the addition of Fe EDTA alone, determined a decline of 15.0 to $48.0 \%$ to $C^{14}$ assimilation and 14.0 to $20.0 \%$ in terms of chlorophyll concentration. The addition made up with nitrate- 
phosphate-vitamins promoted and enhancement from 24.0 to $72.0 \%$ to carbon assimilation and from 2.0 to $16.0 \%$ to chlorophy11 concentration against to the controls. Nevertheless the enrichment with vitamins alone, produced a decline of 35.0 to $52.0 \%$ to carbon assimilation and a fairly stimulus on the chlorophy11 synthesis from 3.0 to $5.0 \%$. A sharp decrease occurred with trace metals from 70.0 to $90.0 \%$ to carbon assimilation and from 12.0 to $25.0 \%$ to chlorophy11 concentration.

TABLE I-Position of the station (Vitória Island) and hydrographic conditions

\begin{tabular}{|c|c|c|c|c|c|c|c|}
\hline Position & Date & $\begin{array}{c}\text { Depth } \\
(\mathrm{m})\end{array}$ & $\begin{array}{c}\mathrm{T} \\
\left({ }^{\circ} \mathrm{C}\right)\end{array}$ & $\begin{array}{c}\mathrm{S} \\
(\% / \mathrm{oo})\end{array}$ & $\begin{array}{c}\mathrm{O}_{2} \\
(\mathrm{cc} / \ell)\end{array}$ & $\mathrm{PO}_{4}-\mathrm{P}$ & $\mathrm{NO}_{3}-\mathrm{N}$ \\
\hline Lat. $23^{\circ} 45^{\prime} \mathrm{S}$ & 09.12 .1972 & 0.0 & 25.15 & 34.83 & 4.95 & 0.04 & 0.10 \\
Long. $45^{\circ} 01^{\prime} \mathrm{W}$ & 09.12 .1972 & 50.0 & 22.40 & 35.04 & 4.07 & 0.56 & 0.31 \\
\hline
\end{tabular}

The unenriched water produced a decline of 72.0 to $88.0 \%$ in terms of carbon assimilation and of 28.0 to $36.0 \%$ to chlorophyll concentration. The experiments with complete enrichments produced, obviously, and increase from 372.0 to $900.0 \%$ to carbon assimilation and from 196.0 to $820.0 \%$ in terms of chlorophy11 concentration. The nitrate-phosphate-silicate also increased from 59.0 to $118.0 \%$ in terms of carbon assimilation and from 31.0 to $113.0 \%$ to chlorophy11 concentration (Figs 1-2).

The results obtained for surface waters showed the following results: the phosphate addition caused inoculum mortality from 8.8 to $33.6 \%$ against the control in terms of carbon assimilation and from 24.0 to $45.0 \%$ to chlorophy11 concentration. However, with the addition of nitrate an increase of $4.0 \%$ to carbon assimilation and of 2.0 to $6.0 \%$ in terms of chlorophyl1 concentration was observed. The combination of nitrate-phosphate was quite relevant and brought about an increase from 3.2 to $20.0 \%$ in carbon assimilation and from 8.0 to $20.0 \%$ in chlorophy 11 concentration. 


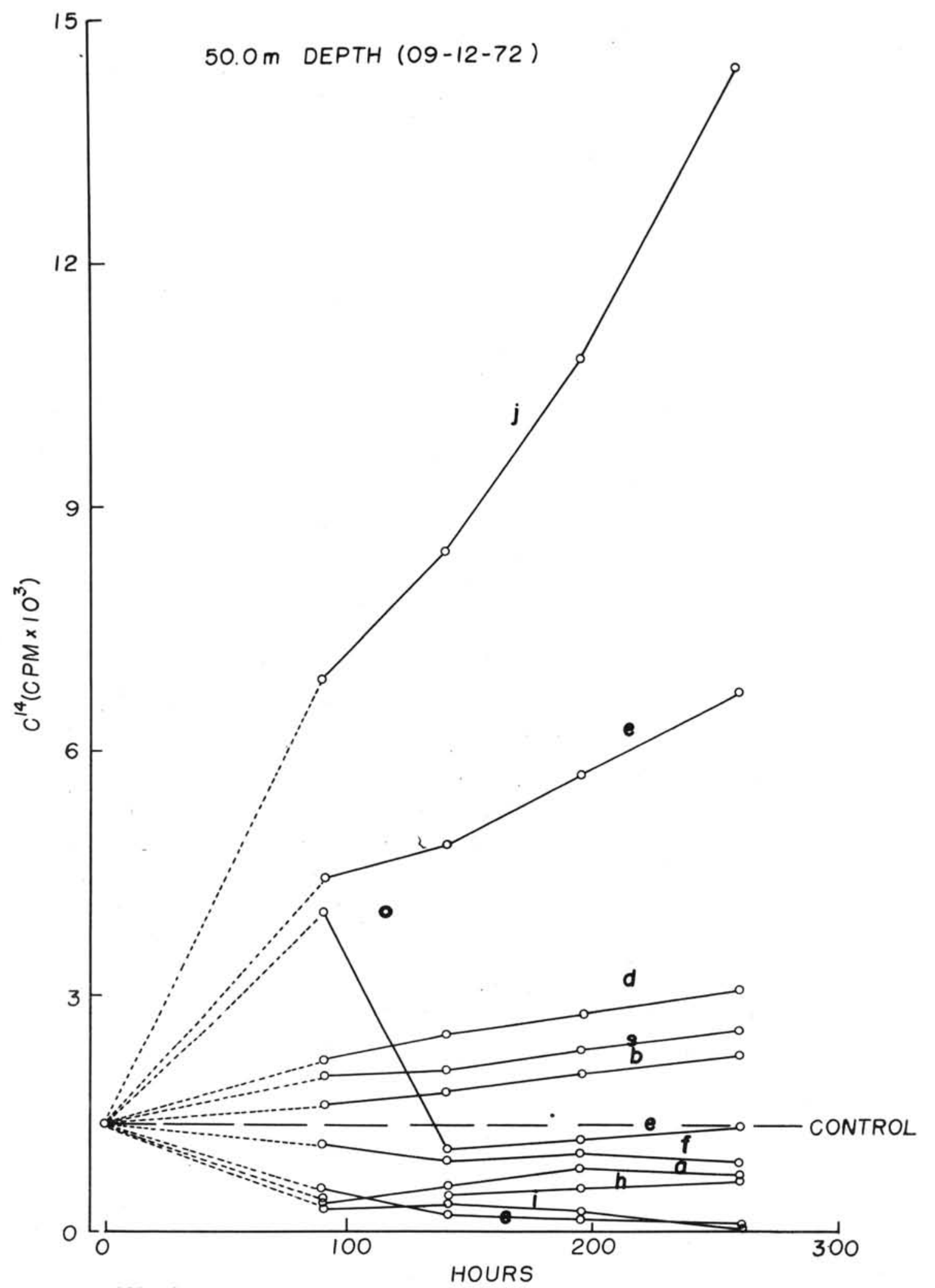

Fig. 1 - The relationship between Carbon-14 assimilation in various enrichments relative to inoculum (control). 


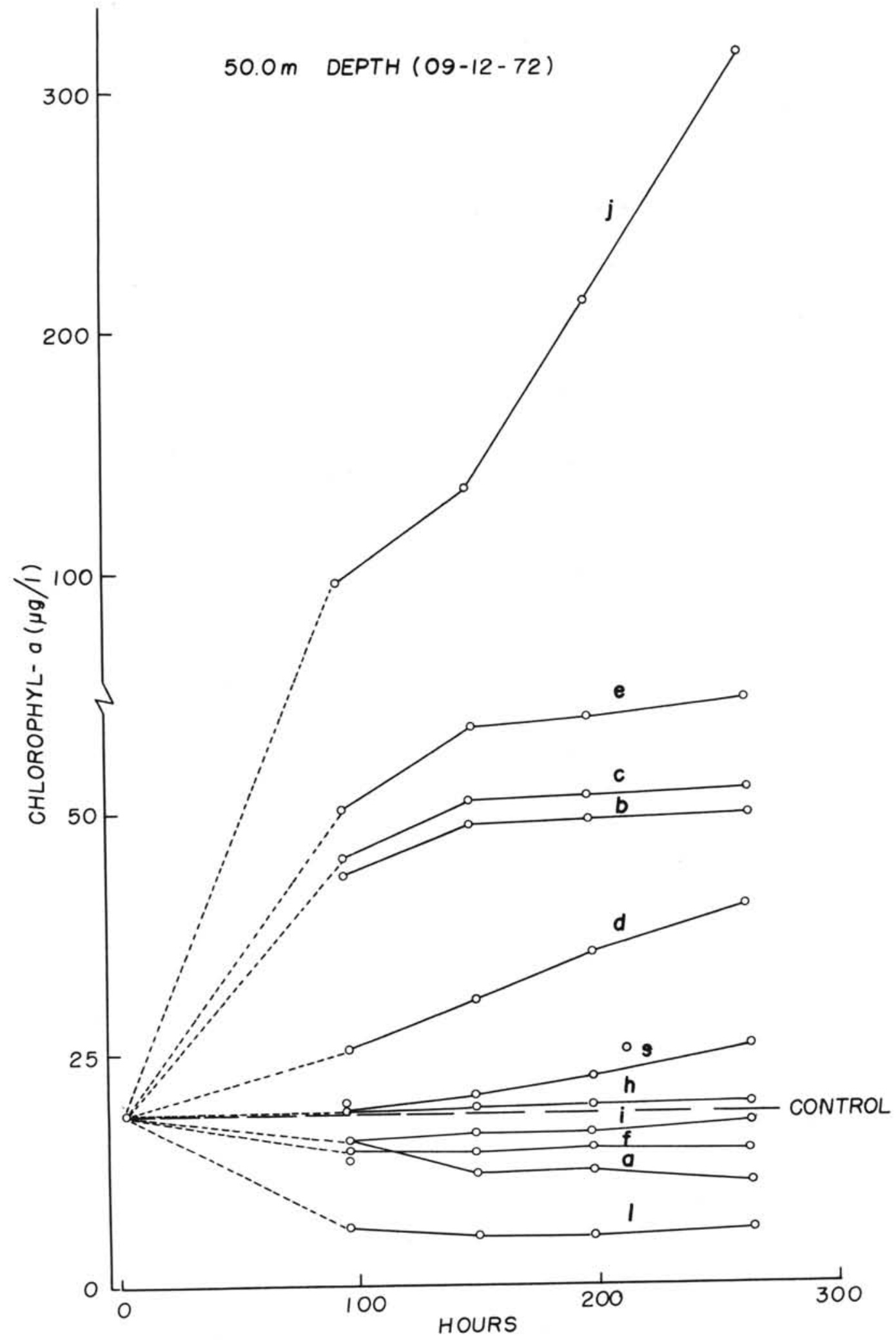

Fig. 2 - The relationship between chlorophyll concentration in various enrichments relative to inoculum (control). 
However, the complete enrichment was highly pronounced, enhancing from 36.0 to $120.0 \%$ as concerns carbon assimilation and from 64.0 to $80.0 \%$ as to chlorophy11 synthesis. The unenrichment water showed a conspicuous decline of 97.0 to $94.0 \%$ to carbon assimilation and from 114.0 to $112.0 \%$ to chlorophy1l concentration. The yield was always considerably inhibited by the addition of the other nutrients (Figs 3-4). The nitrate-phosphate-silicate increased from 2.5 to $12.0 \%$ as to carbon assimilation and from 3.0 to $6.0 \%$ as to chlorophy11 concentration.

\section{DISCUSSION}

The primary production of the region under study is low (Teixeira, 1973) and the nutrients analysed demonstrated extremely low levels insufficient to support a more dense phytoplankton population (Table I). From the results presented in this paper, we may conclude that any nutrients deficiency becomes seriously limiting to primary production of this marine area. This is confirmed by no increase in the $\mathrm{C}^{14}$ fixations and chlorophyll concentration which occurred in unenriched samples in the controls. Based on these investigations, nitrogen as $\mathrm{NaNO}_{3}$ was found to be a primary limiting factor for phytoplankton production; phosphorus did not appear to be as critical as nitrate.

The data from the bioassay carried out near Vitoria Island (Table I) at surface and at $50.0 \mathrm{~m}$ depth, allow to infer the following comments: the addition of phosphate did not produce growth and therefore the inoculum diminished in relation to control in terms of both $\mathrm{C}^{14}$ assimilation and chlorophy11 concentration (Figs 1-4). On the other hand a pronounced growth of Phaeodactylum tricornutum was observed in the samples with nitrate enrichments, confirmed by the increases on carbon assimilation and chlorophyll 
synthesis (Figs 1-4). These data suggest that nitrogen represents a primary limiting factor and phosphorus a secondary limiting factor. The increase in the photosynthesis rate was threefold in relation to chlorophyll concentration, and therefore we may conclude that the nitrate-phosphate enrichment probably must influence mainly the photosynthetic-enzymes synthesis.

The addition of nitrate-phosphate-Fe EDTA, produced only a temporary increase of carbon assimilation; however concerning the chlorophy11 concentration, the effects obtained were significant (Fig. 2). Without nitratephosphate nutrients, the Fe EDTA always caused inoculum mortality in the samples (Figs 3-4). Adding vitamins to nitrate-phosphate enrichments, only a fairly development on the growth occurred (Figs 1-2) and the addition of vitamins alone determined a decrease (Figs 1-4).

The response to trace metals addition showed similar results when related to vitamins. Under the environmental culture conditions described, the enrichment free water did not support any growth. A decline in carbon assimilation and in chlorophyl1 concentration was obtained, but the carbon assimilation was more accentuated. Such tendency of unenriched water to be less favorable to carbon assimilation than to chlorophyll concentration may be related to cells excretion, as suggested by Fogg (1958).

The experiments with enriched surface waters collected at the same station (Table I), demonstrated that these waters are less favorable for the growth of $P$. tricornutum than those from $50.0 \mathrm{~m}$ depth. They show evidence of the importance played by nitrate, nitrate plus phosphate and complete medium, which not only avoided the inoculum lysis, but also enhanced the growth and the photosynthesis rates under the environmental conditions referred previously. In fact, with the nitrate absence the other nutrients additions separatelly were not suitable to bring about cell growth or promoted it slightly. The experiments made with complete enrichment induce the best growth found for the general treatments. These experiments confirm the idea that nitrogen is the key of limiting nutrient. The growth of algae should demand, first of all, the supply of nitrogeneous compounds. 


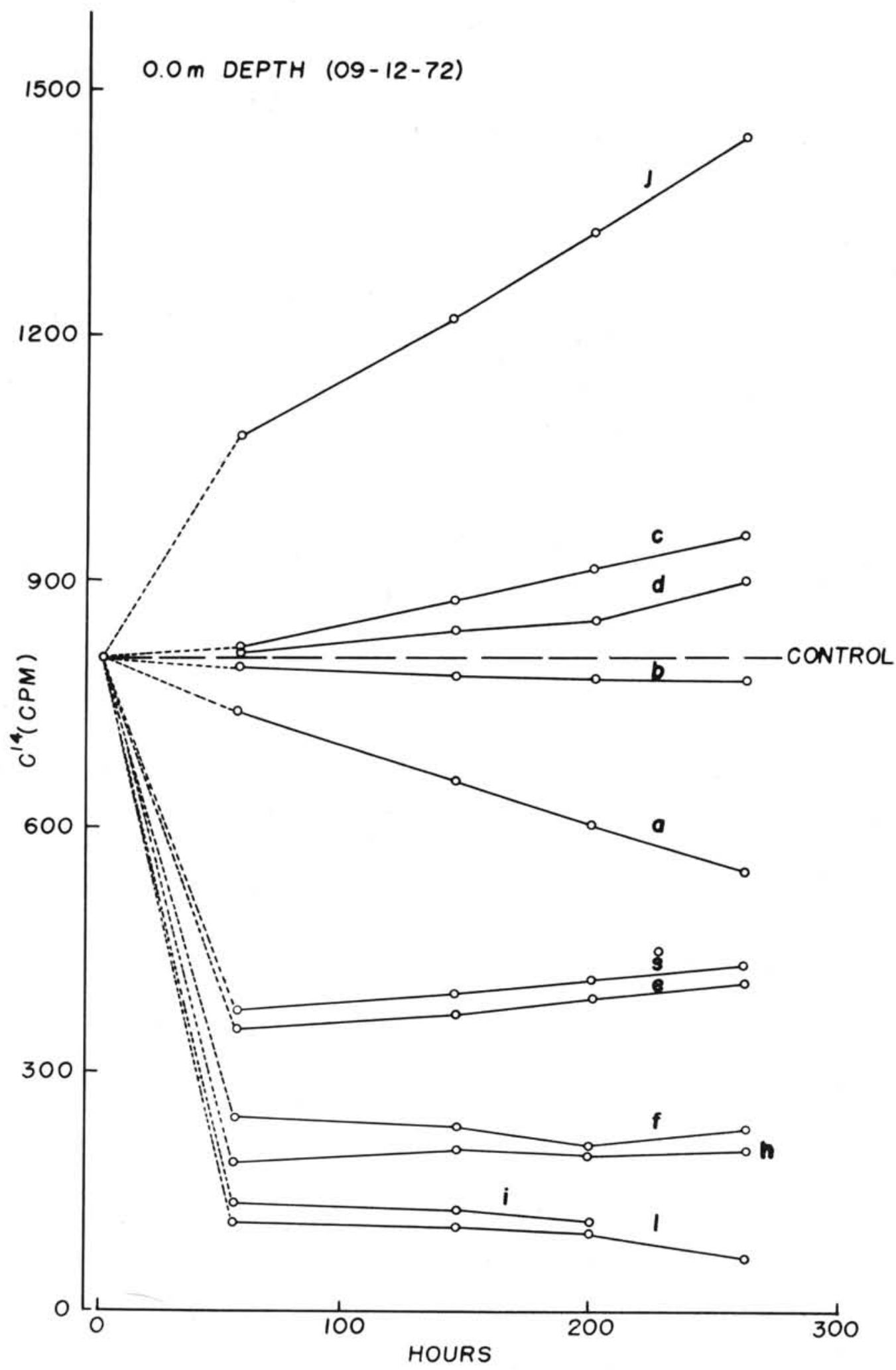

Fig. 3 - The relationship between Carbon-14 assimilation in various enrichments relative to inoculum (control). 


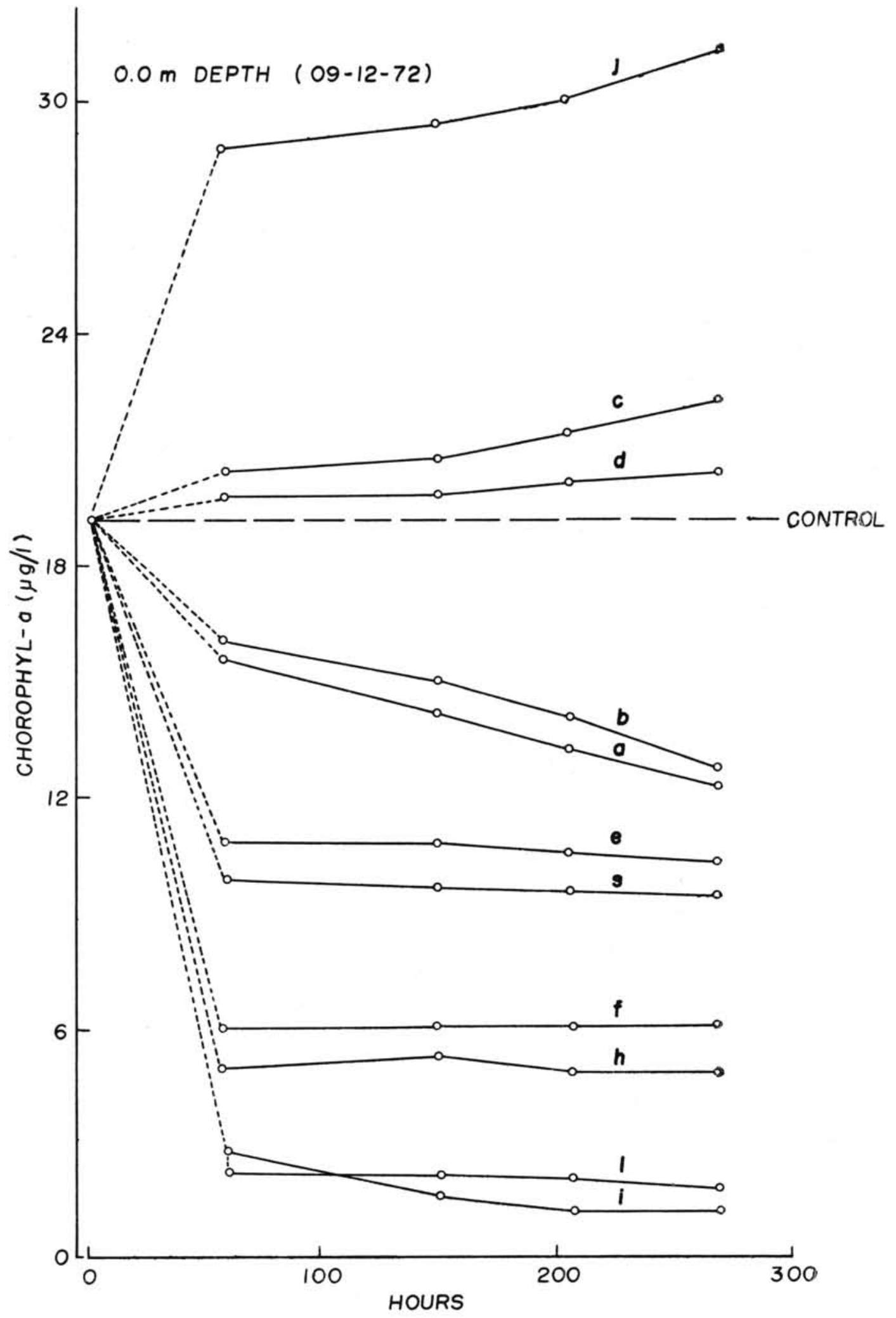

Fig. 4 - The relationship between chlorophyll concentration in various enrichments relative to inoculum (control). 
Bolm Inst. oceanogr., S Paulo, 25, 1976

\section{SUMMARY}

The growth of Phaeodactylum tricornutum, incubated at 7,000 1ux and $25^{\circ} \mathrm{C}$ for twelve days, in enrichment experiments using filtered water collected at surface and at $50.0 \mathrm{~m}$ depth at one station near Vitoria Island during September 1972 is studied. The occurrence of "poor" water, when unenriched, which caused inoculum mortality, is demonstrated. The addition of nitrate and phosphate always stimulated the growth of the inoculum. Nitrate omission limited the growth. The response against the addition of trace metals and vitamins, when alone, caused inoculum mortality. The nitrogen was found to be a primary limiting factor for phytoplankton production.

RESUMO

Este trabalho teve como finalidade avaliar a qualidade das águas costeiras coletadas num ponto nas proximidades da Ilha Vitōria (Lat. $23^{\circ} 45^{\prime} \mathrm{S}-$ Long. $\left.45^{\circ} 01^{\prime} \mathrm{W}\right)$, na superfície e a $50,0 \mathrm{~m}$ de profundidade.

Foram realizadas 176 ensaios biológicos com o auxílio de Phaeodactylum tricornutum, incubada em dez diferentes combinações de meios, alēm do controle.

As respostas às diferentes condições ambientais fornecidas as culturas, foram obtidas baseando-se na diferenciação da biomassa em termos de clorofila-a, e na realização da fotossintese em termos da assimilação do carbono14.

Os resultados demonstraram ser o nitrogênio o fator limitante primärio para o crescimento do fitoplâncton. 


\section{ACKNOWLEDGEMENTS}

The authors whishes to express the best thanks to Dr. Falcão Paredes by the appreciation in preparing the manuscript, and to the "Fundação de Amparo à Pesquisa do Estado de São Paulo" for the grant awarded to the junior author.

\section{REFERENCES}

FOGG, G. E. 1958. Extracellular products of phytoplankton and the estimation of primary production. Rapp. P.-v. Réun. Cons. perm. int. Explor. Mer, 144:56-60.

GUILLARD, R. R. L. 1963. Organic sources of nitrogen for marine centric diatoms. Chap. 9, In: Openheiner, C. H., ed. - Symposium on marine microbiology. Springfield, I11., C. H. Thomas, p. 93-104.

MENZEL, D. W. \& RYTHER, J. H. 1961. Annual variations in primary production of the Sargasso Sea, off Bermuda. Deep Sea Res., 7:282-288.

PARSONS, T. R. \& STRICKLAND, J. D. H. 1963. Discussion of spectrophotometric determination of marine plant pigments, with revised equations for ascertaining chlorophyll and carotenoids. J. mar. Res., $21: 155-163$.

RICHARDS, F. A. \& THOMPSON, T. G. 1952. The estimation and characterization of plankton population by pigment analysis. II. A spectrophotometric method for the estimation of plankton pigments. J. mar. Res., 11(2):156-172.

RYTHER, J. H. \& GUILLARD, R. R. L. 1960. Studies of marine planktonic diatoms. III. Detonula solitaria as an assay organism for vitamin $\mathrm{B}_{12}$. Woods Hole Oceanographic Institution, Appendix XI to Ref. 60-6:1-5. 
SMAYDA, T. J. 1964. Enrichment experiments using the marine centric diatom Cyclotella nana (clone 13-1) as an assay organism. Oc. Pub1. Grad. School Oceanogr. Univ. Rhode Island, (2):25-32.

TEIXEIRA, C. 1973. Preliminary studies of primary production in the Ubatuba region (Lat. $23^{\circ} 30^{\prime} \mathrm{S}$ - Long. $45^{\circ} 06^{\prime} \mathrm{W}$ ), Brazil. Bolm Inst. oceanogr., S Paulo, 22:49-58.

(Recebido em 07/0utubro de 1974) 